\title{
Effects of dietary probiotic and prebiotic supplementation on growth performance and serum IgG concentration of broilers
}

\author{
M. Midilli' ${ }^{1 \#}$, M. Alp ${ }^{2}$, N. Kocabağlı ${ }^{2}$, Ö.H. Muğlalı ${ }^{3}$, N. Turan ${ }^{4}$, H. Yılmaz ${ }^{5}$ and S. Çakır ${ }^{1}$ \\ ${ }^{1}$ University of Abant Izzet Baysal, Mudurnu Süreyya Astarcı Vocational School of Higher Education, Department of \\ Poultry Science, Bolu, Turkey \\ ${ }^{2}$ University of Istanbul, Veterinary Faculty, Department of Animal Nutrition and Nutritional Diseases, Istanbul, Turkey \\ ${ }^{3}$ University of Ondokuz May1s, Veterinary Faculty, Department of Animal Nutrition and Nutritional Diseases, Samsun, \\ Turkey \\ ${ }^{4}$ University of Istanbul, Veterinary Faculty, Department of Microbiology, Istanbul, Turkey \\ ${ }^{5}$ University of Istanbul, Veterinary Faculty, Department of Virology, Avc1lar, Istanbul, Turkey
}

\begin{abstract}
This study was conducted to investigate the effects of probiotic and/or prebiotic supplementation on growth performance and serum IgG concentrations in broilers. One thousand two hundred one-day old Ross308 broiler chicks of mixed sex were randomly divided into four treatment groups of 300 birds each. The treatments were: Starter diets: 1) Unsupplemented control diet; 2) Probiotic (Bio-Plus $2 \mathrm{~B}^{\circledR}$ 0.05\%); 3) Prebiotic (Bio-Mos ${ }^{\circledR} 0.2 \%$ ); 4) Probiotic and Prebiotic mixture (Bio-Plus $2 \mathrm{~B}^{\circledR} 0.05 \%$ and Bio-Mos ${ }^{\circledR} 0.2 \%$ ). The grower diets were: 1) Control with no supplements; 2) Probiotic (Bio-Plus $2 \mathrm{~B}^{\circledR} 0.05 \%$ ); 3 ) Prebiotic $\left(\right.$ Bio-Mos ${ }^{\circledR} 0.1 \%$ ); 4) Probiotic and Prebiotic mixture (Bio-Plus $2 \mathrm{~B}^{\circledR} 0.05 \%$ and Bio-Mos ${ }^{\circledR} 0.1 \%$ ). Each treatment group was further sub-divided into five replicates of 60 birds per replicate. The chicks were fed the broiler starter diet for the first $21 \mathrm{~d}$ and the broiler grower diet between days 22 and 42 . Dietary probiotic and/or prebiotic supplementation did not significantly affect body weight, body weight gain, feed intake, carcass weight, carcass yield or concentration of immunoglobulin (IgG) in the serum. However, feed conversion ratio was improved significantly in the supplemented treatments compared to the unsupplemented control. Probiotic and/or prebiotic supplementation did not significantly affect any of the examined parameters except for an improved feed conversion ratio.
\end{abstract}

Keywords: Probiotic, prebiotic, broilers, performance

\#Corresponding author. E-mail: mmidilli@yahoo.com, midilli_m@ibu.edu.tr

\section{Introduction}

Worldwide, antibiotics have been used for decades in animal production. At low levels of inclusion in diets antibiotics have proven to enhance growth performance in farm animals. However, due to the emergence of microbes resistant to antibiotics used to treat infections in humans and animals, the Europe Union Commission decided to phase out and ultimately ban the marketing and including of antibiotics as growth promoters in animal diets. This ban became effective on January 1, 2006 (Europe Union Commission, 2005). Consequently the focus in research has switched to feed additives as alternatives to antibiotics in poultry diets, apparently primarily to ensure gut health. Several possible mechanisms have been suggested such as altering of the gut $\mathrm{pH}$, maintaining protective gut mucins, selecting beneficial intestinal organisms or ones antagonistic to pathogens, enhancing fermentation acids, enhancing nutrient uptake or increasing the humoral immune response (Inboor et al., 2000). These alternative feed additives include products such as enzymes, herbal products, microflora enhancers, immunomodulators, organic acids, probiotics, prebiotics or combinations of these products.

Under certain conditions probiotics alter the intestinal microbiota and immune system to reduce colonization by pathogens (Patterson \& Burkholder, 2003). Numerous studies in humans and animals have been conducted to assess the ability of probiotics to change the type and number of the microflora in the digestive tract (Walker \& Duffy, 1998; Gibson \& Fuller, 2000). Some investigations on probiotics and organic acids with broiler chicks indicated positive responses to dietary supplementation (Mohan et al., 
1996; Midilli \& Tuncer, 2001). In addition, Yeo \& Kim (1997) observed significant improvements in daily body weight gain and feed intake in broiler chicks receiving probiotics.

Another method that may be used to manipulate the gut ecosystem is the supplementation of the diet with small fragments of carbohydrates. These carbohydrates, known as prebiotics, are also alternatives to antibiotics in the diet. Ammerman et al. (1989) reported that broilers receiving a diet supplemented with $0.375 \%$ oligofructose produced heavier birds at 47 days and improved percentage carcass and breast weights while the percentage fat pad was lower than in the unsupplemented group. Probiotics and prebiotics may enhance health by stimulating antibody production (Savage et al., 1996). Limited studies have been conducted to determine the effects of probiotics and prebiotics on serum immunoglobulin (IgG) concentrations (Çetin et al., 2005; Haghighi et al., 2006). Furthermore, where different species of birds were used, conflicting results on serum IgG concentrations have been observed.

All animals reared under commercial field conditions are subjected to immunological stress, especially in the early stages of life. This depends on the pathogen load in their environment. When the microorganism load in the gut is unbalanced, beneficial results could be achieved through the use of dietary probiotics and/or prebiotics. Due to the ban on the use of antibiotics as growth promoters in poultry diets investigations evaluating the potential of dietary probiotics and/or prebiotics as substitutes for antibiotics should receive high priority. This experiment was carried out to determine possible effects of dietary probiotics and/or prebiotics as growth promoters on broiler performance and their serum IgG concentrations.

\section{Materials and Methods}

One thousand two hundred one-day old broiler chicks were obtained from a commercial hatchery, weighed and randomly allocated to four experimental groups of 300 birds per group. The experimental design consisted of four dietary treatments: 1) unsupplemented control diet; 2) a probiotic containing $2.3 \times 10^{8}$

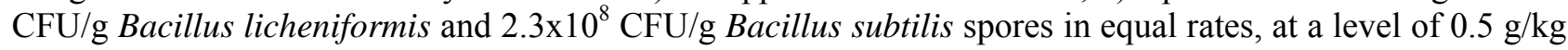
from days 1 to 42 (Bio-Plus 2B®, Chr. Hansen A/S, Horsholm, Denmark); 3) a prebiotic at a level of $2 \mathrm{~g} / \mathrm{kg}$ from days 1 to 21 and $1 \mathrm{~g} / \mathrm{kg}$ from days 22 to 42 (Bio-Mos ${ }^{\circledR}$; a mannanoligosaccharide derived from the cell walls of the yeast Saccharomyces cerevisiae, Alltech, Nicholasville, KY, USA); 4) a combination of the probiotic and prebiotic at the same levels as given above. The commercial probiotics and prebiotics were used according to the manufacturers' instructions.

Each group was divided into five replicates of 60 birds per replicate. For the experimental period of six week the birds in each replicate were placed into a pen with a floor area of $3 \mathrm{~m} \mathrm{x} 3 \mathrm{~m}$ and a height of 120 $\mathrm{cm}$. Wood shavings were used as bedding material on the concrete floor and each pen contained a single feeder and drinker. The broiler starter and grower diets were based on maize and soyabean meal. The chicks were fed a broiler starter diet from days 1 to 21 and a broiler grower diet from days 22 to 42 . The composition of the experimental diets is shown in Table 1. Nutrient levels of the diets for broilers were based on the NRC (1994) recommendations on nutrient requirements of broiler chickens. All chicks had free access to feed and water. Brooder lamps provided supplemental heat in each pen and house temperature was set at $34{ }^{\circ} \mathrm{C}$ for the first $5 \mathrm{~d}$ and then gradually reduced according to normal management practices, until a temperature of $23{ }^{\circ} \mathrm{C}$ was reached. A photoperiod of $23 \mathrm{~h}$ light and $1 \mathrm{~h}$ dark was used.

Performance data were recorded weekly in the periods from 1 to 42 days of age. Feed intake was determined for each repetition as the difference between the amount of feed supplied and the remaining feed at the end of each experimental period. Body weight and body weight gain were calculated as the difference between the final and initial bird weights. Feed conversion ratio was calculated as the ratio between feed intake and body weight gain during each phase of the experimental period. Feed was removed from each pen $12 \mathrm{~h}$ prior to processing. Ten male broilers per group (two birds per replicate) were selected and individually weighed just prior to slaughter at the end of the experiment. These selected birds were slaughtered and used for determination of carcass weight and carcass yield without feet, head and neck. At the beginning of the study, 40 one-day old broiler chicks were killed and the blood samples were collected to determine serum IgG concentrations of the chicks at the onset of the study. Blood samples of two chicks randomly selected from each pen, were collected at 42 days for determination of serum IgG concentrations. The method used in 
Table 1 Ingredients and chemical composition of the experimental starter and grower diets (dry matter basis)

\begin{tabular}{|c|c|c|c|c|c|c|c|c|}
\hline & \multicolumn{4}{|c|}{1 to 21 days (Starter) } & \multicolumn{4}{|c|}{22 to 42 days (Grower) } \\
\hline & Control & Probiotic & Prebiotic & $\begin{array}{l}\text { Probiotic \& } \\
\text { Prebiotic }\end{array}$ & Control & Probiotic & Prebiotic & $\begin{array}{c}\text { Probiotic \& } \\
\text { Prebiotic }\end{array}$ \\
\hline \multicolumn{9}{|l|}{ Ingredients $(\mathrm{g} / \mathrm{kg})$} \\
\hline Maize & 510.0 & 510.0 & 510.0 & 510.0 & 526.5 & 526.5 & 526.5 & 526.5 \\
\hline Wheat & 39.5 & 39.0 & 38.5 & 38.0 & 46.0 & 46.0 & 46.0 & 46.0 \\
\hline Wheat bran fine middling & - & - & - & - & 44.5 & 44.0 & 43.5 & 43.0 \\
\hline Soyabean meal $(46 \% \mathrm{CP})$ & 246 & 246 & 246 & 246 & 190 & 190 & 190 & 190 \\
\hline Full-fat soya & 75 & 75 & 75 & 75 & 70 & 70 & 70 & 70 \\
\hline Fish meal $(67 \% \mathrm{CP})$ & 66 & 66 & 66 & 66 & 55 & 55 & 55 & 55 \\
\hline Sunflower oil (37.4 MJ/kg) & 30 & 30 & 30 & 30 & 40 & 40 & 40 & 40 \\
\hline Limestone & 11.5 & 11.5 & 10.5 & 10.5 & 10.0 & 10.0 & 10.0 & 10.0 \\
\hline Dicalcium phosphate $^{1}$ & 13.5 & 13.5 & 13.5 & 13.5 & 9.5 & 9.5 & 9.5 & 9.5 \\
\hline Vitamin-mineral premix ${ }^{2}$ & 2.5 & 2.5 & 2.5 & 2.5 & 2.5 & 2.5 & 2.5 & 2.5 \\
\hline Salt & 2.5 & 2.5 & 2.5 & 2.5 & 2.5 & 2.5 & 2.5 & 2.5 \\
\hline DL-Methionine & 1.5 & 1.5 & 1.5 & 1.5 & 1.5 & 1.5 & 1.5 & 1.5 \\
\hline Coccidiostat $^{3}$ & 1.0 & 1.0 & 1.0 & 1.0 & 1.0 & 1.0 & 1.0 & 1.0 \\
\hline Antioxidant ${ }^{4}$ & 1.0 & 1.0 & 1.0 & 1.0 & 1.0 & 1.0 & 1.0 & 1.0 \\
\hline Bio-Plus $2 \mathrm{~B}^{5}$ & - & 0.5 & - & 0.5 & - & 0.5 & - & 0.5 \\
\hline Bio-Mos ${ }^{6}$ & - & - & 2.0 & 2.0 & - & & 1.0 & 1.0 \\
\hline \multicolumn{9}{|l|}{ Calculated nutrient content ${ }^{7}(\mathrm{~g} / \mathrm{kg})$} \\
\hline Metabolisable energy, $\mathrm{MJ} / \mathrm{kg}$ & 13.2 & 13.2 & 13.2 & 13.2 & 13.5 & 13.5 & 13.5 & 13.5 \\
\hline Crude protein & 236 & 236 & 236 & 236 & 210 & 210 & 210 & 210 \\
\hline Lysine & 14.1 & 14.1 & 14.1 & 14.1 & 12.1 & 12.1 & 12.1 & 12.1 \\
\hline Methionine & 5.4 & 5.4 & 5.4 & 5.4 & 5.0 & 5.0 & 5.0 & 5.0 \\
\hline Methionine + cystine & 8.6 & 8.6 & 8.6 & 8.6 & 7.7 & 7.7 & 7.7 & 7.7 \\
\hline Total calcium & 11 & 11 & 11 & 11 & 9 & 9 & 9 & 9 \\
\hline Total phosphorus & 5 & 5 & 5 & 5 & 4 & 4 & 4 & 4 \\
\hline
\end{tabular}

${ }^{1}$ Contains $24 \% \mathrm{Ca}$ and $17.5 \%$ available $\mathrm{P}$.

${ }^{2}$ Supplied the following per kilogram of diet: 15000 IU vitamin A; 1500 ICU cholecalciferol; 30 IU vitamin E (dl- $\alpha$-tocopheryl acetate); 5 mg menadione; 3 mg thiamine; $6 \mathrm{mg}$ riboflavin; $20 \mathrm{mg}$ niacin; $8 \mathrm{mg}$ panthotenic acid; $5 \mathrm{mg}$ pyridoxine; $1 \mathrm{mg}$ folic acid; $15 \mu \mathrm{g}$ vitamin $\mathrm{B}_{12} ; 80 \mathrm{mg}$ manganese; $60 \mathrm{mg}$ zinc; $30 \mathrm{mg}$ iron; 5 mg copper; $2 \mathrm{mg}$ iodine; $0.15 \mathrm{mg}$ selenium.

${ }^{3}$ Cygro; ${ }^{4}$ Ethoxyquin; ${ }^{5}$ per g contains $2.3 \times 10^{8}$ Bacillus licheniformis and $2.3 \times 10^{8}$ Bacillus subtilis spores in equal rates.

${ }^{6}$ Mannanoligosaccharide preparation (Bio-Mos) of Alltech Inc., Nicholasville KY, ${ }^{7}$ According to AOAC (1990). 
ELISA was the combination of methods as described previously (Erhard et al., 1992; Li et al., 2000). In the present study the suitable serum dilution was found to be 1: 200. The most suitable monoclonal antibody dilution for coating the plates was found to be $5 \mu \mathrm{g} / \mathrm{mL}$. The linearity of the standard IgG was calculated using Excel, and found to be $\mathrm{R}^{2}=0.98$.

All data were analyzed by ANOVA using SPSS Inc. (1999) program. Significant differences among treatments were determined using the Duncan's multiple range test with a 5\% level of probability.

\section{Results and Discussion}

For the past decades antibiotic growth promoters have been included as a standard practice in poultry diets worldwide at sub-therapeutic concentrations because of their positive effects on body weight, body weight gain and feed conversion ratio. The present study was carried out to evaluate the effect of a probiotic and/or a prebiotic on the growth performance and serum IgG concentrations of broilers. Strategic use of these alternative compounds should assist in optimizing growth provided they are used in such a way that their modes of action can complement one another. Body weight, body weight gain, feed intake, feed conversion ratio, carcass weight and carcass yield of broilers from days 1 to 42 are presented in Table 2 . Body weight and body weight gain of the broilers were not significantly influenced by probiotic and/or prebiotic supplementation. This is in agreement with research in which it was found that body weight and body weight gain in broilers were not affected by the supplementation of probiotics (Alp et al., 1993) or prebiotics (Waldroup et al., 2003). However, other researchers have previously demonstrated significant increases in body weight gain in broilers receiving diets supplemented with probiotics (Midilli \& Tuncer, 2001) and prebiotics (Piray et al., 2007).

The improvement in feed intake by dietary probiotic and prebiotic supplementation often resulted in improved growth performance. However, in the present study, using the specific additives, no differences were observed in feed intake and consequently in body weight and body weight gain between treatments. Similar results for probiotics were reported by Gohain \& Sapcota (1998) and for prebiotics by Sims \& Sefton (1999). However, in a series of experiments dietary probiotics (Safalaoh, 2006) and prebiotics (Sanchez \& Ayaya, 1998) have been shown to increase feed intake. At $6 \mathrm{wk}$ of age the additives led to significant changes $(\mathrm{P}<0.05)$ in the feed conversion ratio $(\mathrm{kg}$ feed $/ \mathrm{kg}$ gain) of broilers compared with the control. Improvements in feed conversion ratios of 3.19, 2.66 and 4.26 percent, respectively, were recorded in the probiotic, prebiotic and probiotic plus prebiotic treatments, compared to the control. This is in agreement with the findings of Sahane et al. (2001) and Pelicia et al. (2004) who suggested this improvement might be due to a better ileal digestibility of nutrients. Dietary treatments did not cause any significant effect on carcass weight and carcass yield. Non-significant changes for carcass traits observed in our study have been reported previously in experiments with probiotics (Khan et al., 1992) and prebiotics (Öztürk \& Yıldırım, 2005).

It is clear from the present study and published research that responses to probiotic and prebiotic supplementation are inconsistent. This led to numerous investigations on possible factors that could influence the responses to these additives. In general these additives have proved most effective under conditions of stress, possibly the presence of unfavourable organisms, extremes in ambient temperature, diseases, crowding and poor management. In commercial broiler production one or more of these conditions are invariably present. Further possible causes of variations in response to probiotic and/or prebiotic supplementation in broilers could be differences between strains, hybrids, age, sex, plane of nutrition, nutrient composition of the diet, microbial population of gastrointestinal tract, levels of inclusion of probiotics and prebiotics in the diet, duration of supplementation or other environmental conditions.

The effects of the probiotic and/or prebiotic on serum IgG concentrations of broilers are given in Table 3. The difference in IgG concentrations between the control and experimental groups was not significant $(\mathrm{P}>0.05)$. These results are in agreement with the results of other studies in which probiotics (Huang et al., 2004) or prebiotics (Franklin et al., 2002) were used in different animal species. However, the present results differ in their response to supplementation studies using a probiotic (Çetin et al., 2005) or a prebiotic (Savage et al., 1996). A possible explanation for the differences between findings of different investigators may be related to the doses of probiotic and prebiotic applied, animal species and study population (e.g. in age, weight or breed), strains of microorganism used and composition of diets. The most 
important reasons for a positive response is the degree of stress in the animals and/or unbalanced microbial populations in the digestive tract.

Table 2 Effects of dietary probiotics, prebiotics or the combination of probiotics and prebiotics on growth performance, carcass weight and carcass yield of broiler chickens

\begin{tabular}{|c|c|c|c|c|c|c|c|}
\hline $\begin{array}{l}\text { Performance } \\
\text { parameters }\end{array}$ & Age & Control & Probiotic & Prebiotic & $\begin{array}{l}\text { Probiotic } \\
\text { \& Prebiotic }\end{array}$ & $\begin{array}{l}\text { Pooled } \\
\text { s.e.m }\end{array}$ & P-value \\
\hline \multicolumn{8}{|l|}{ Body weight (g) } \\
\hline & $1 \mathrm{~d}$ & 37.5 & 37.6 & 38.1 & 37.8 & 0.1 & NS \\
\hline & $21 \mathrm{~d}$ & 816 & 822 & 818 & 827 & 2.1 & NS \\
\hline & $42 \mathrm{~d}$ & 2295 & 2312 & 2314 & 2317 & 5.7 & NS \\
\hline \multicolumn{8}{|l|}{ Body weight gain (g) } \\
\hline & 1 to 21 & 779 & 776 & 780 & 790 & 7.8 & NS \\
\hline & 21 to $42 \mathrm{~d}$ & 1478 & 1499 & 1495 & 1490 & 15.1 & NS \\
\hline & 1 to $42 \mathrm{~d}$ & 2257 & 2274 & 2276 & 2279 & 18.6 & NS \\
\hline \multicolumn{8}{|l|}{ Feed intake $(\mathrm{g})$} \\
\hline & 1 to $21 \mathrm{~d}$ & 1217 & 1131 & 1182 & 1158 & 14.4 & NS \\
\hline & 21 to $42 \mathrm{~d}$ & 3015 & 2905 & 2851 & 2798 & 38.6 & NS \\
\hline & 1 to $42 \mathrm{~d}$ & 4233 & 4142 & 4161 & 4113 & 36.8 & NS \\
\hline \multicolumn{8}{|c|}{ Feed conversion ratio ( $\mathrm{g}$ feed/g gain) } \\
\hline & 1 to $21 \mathrm{~d}$ & $1.56^{\mathrm{a}}$ & $1.46^{\mathrm{c}}$ & $1.51^{\mathrm{b}}$ & $1.47^{\mathrm{c}}$ & 0.01 & $0.003^{* *}$ \\
\hline & 21 to $42 \mathrm{~d}$ & $2.04^{\mathrm{a}}$ & $1.94^{\mathrm{b}}$ & $1.91^{\mathrm{b}}$ & $1.88^{b}$ & 0.02 & $0.005^{* *}$ \\
\hline & 1 to $42 \mathrm{~d}$ & $1.88^{\mathrm{a}}$ & $1.82^{\mathrm{b}}$ & $1.83^{\mathrm{b}}$ & $1.80^{\mathrm{b}}$ & 0.01 & $0.02 *$ \\
\hline \multicolumn{8}{|l|}{ Carcass parameters } \\
\hline Carcass weight (g) & $42 \mathrm{~d}$ & 1686.2 & 1691.9 & 1644.0 & 1659.7 & 17.9 & NS \\
\hline Carcass yield $(\%)$ & $42 \mathrm{~d}$ & 72.5 & 71.9 & 72.6 & 72.1 & 0.1 & NS \\
\hline
\end{tabular}

$\overline{\mathrm{a}-\mathrm{c}}$ Mean values within a row having different superscripts are significantly different at: $*(\mathrm{P}<0.05), * *(\mathrm{P}<0.01)$; NS - not significant.

s.e.m. - Standard error of the differences among (or between) means.

Table 3 Effects of dietary treatments on serum immunoglobulin $\mathrm{G}(\mathrm{IgG})$ concentrations

\begin{tabular}{lrrrrrrr}
\hline Variables & Age & Control & Probiotic & Prebiotic & $\begin{array}{c}\text { Probiotic \& } \\
\text { Prebiotic }\end{array}$ & $\begin{array}{l}\text { Pooled } \\
\text { s.e.m }\end{array}$ & P-value \\
\hline Serum IgG concentrations (mg/dL) & & & & & & \\
& $1 \mathrm{~d}$ & 14.9 & 13.9 & 13.4 & 14.9 & 0.3 & NS \\
& $42 \mathrm{~d}$ & 7.4 & 7.4 & 7.1 & 7.8 & 0.1 & NS \\
\hline
\end{tabular}

NS - not significant.

s.e.m. - Standard error of the differences among (or between) means.

\section{Conclusion}

This study provides evidence that the administration of probiotics and/or prebiotics to broiler diets did not cause any significant changes on broiler performance with the exception of feed conversion ratio. Serological data from the present study also showed the ineffectiveness of additive supplementation on systemic IgG. Although non-significant results were observed for the examined parameters, further studies are needed to understand the effects of these additives and to clarify the effect on immune response of broilers. More comprehensive experimental designs examining performance and humoral immunities especially IgG, dose-related effects of age and/or strain-host interactions, should be conducted. 


\section{Acknowledgement}

This study was supported by the Scientific Research Fund of Abant Izzet Baysal University (2003.24.24.148), Turkey, and is gratefully acknowledged by the authors.

\section{References}

Alp, M., Kahraman, R., Kocabağli. N., Eren, M. \& Şenel, S.H., 1993. The effects of lactiferm-15 and some antibiotics on performance, abdominal fat, intestinal tract weight and blood cholesterol levels of broilers. Vet. J. Istanbul Univ. 19, 145-157. (Turkish with English summary).

Ammerman, E., Quarles, C. \& Twining, P.V., 1989. Evaluation of fructooligosaccharides on performance and carcass yield of male broilers. Poult. Sci. 68, (Suppl. 1), 167. (Abstr.).

AOAC, 1990. Officials Methods of Analysis (15th ed.). Association of Official Analytical Chemists, Inc., Arlington, Virginia, USA.

Çetin, N., Güçlü, B.K. \& Çetin, E., 2005. The effects of probiotics and mannanoligosaccharide on some haematological and 1mmunological parameters in Turkeys. J. Vet. Med. A. 52, 263-267.

Erhard, M.H., Von Quistorp, I., Schranner, I., Jungling, A., Kaspers, B., Schmidt, P. \& Kuhlmann, R., 1992. Development of specific enzyme-linked immunosorbent antibody assay systems for the detection of chicken immunoglobulins G, M, and A using monoclonal antibodies. Poult. Sci. 71, 302-310.

Europe Union Commission, 2005. Ban on antibiotics as growth promoters in animal feed enters into effect. Regulation 1831/2003/EC on additives for use in animal nutrition, replacing Directive 70/524/EEC on additives in feed-stuffs, Brussels, 22 December.

Franklin, S.T., Newman, K.E. \& Newman, M.C., 2002. Evaluation of mannanoligosaccharide on the immune status of dairy cows and their calves. J. Anim. Sci. 80, 192.

Gibson, G.R. \& Fuller, F., 2000. Aspects of in vitro and in vivo research approaches directed toward identifying probiotics and prebiotics for human use. J. Nutr. 130, 391-395.

Gohain, A.K. \& Sapcota, D., 1998. Effect of probiotic feeding on the performance of broilers. Indian J. Poult. Sci. 33, 101-105.

Haghighi, R.H., Gong, J., Gyles, L.C., Hayes, M.S., Zhou, H., Sanei, B., James, R., Chambers, R.J. \& Sharif, S., 2006. Probiotics stimulate production of natural antibodies in chickens. Clin. Vacc. Immunol. 13, 975-980.

Huang, M.K., Choi, Y.J., Houde, R., Lee, J.W., Lee, B. \& Zhao, X., 2004. Effects of Lactobacilli and an acidophilic fungus on the production performance and immune responses in broiler chickens. Poult. Sci. 83, 788-795.

Inboor, J., 2000. Swedish poultry production without feed antibiotics: A testing ground or a model for the future? Aust. Poult. Sci. Symp. 12, 1-9.

Khan, M.L., Ulah, I. \& Javed, M.T., 1992. Comparative study of probiotics, tm. 50 biovin-40 and albac on the performance of broiler chicks. Pakistan Vet. J. 12, 145-157.

Li, Z., Nestor, K.E., Saif, Y.M., Anderson, J.W. \& Patterson, R.A., 2000. Serum immunoglobulin G and M concentrations did not appear to be associated with resistance to Pasteurella multocida in a largebodied turkey line and a random bred control population. Poult. Sci. 79, 163-166.

Midilli, M. \& Tuncer, Ş.D., 2001. The effects of enzyme and probiotic supplementation to diets on broiler performance. Turk. J. Vet. Anim. Sci. 25, 895-903. ( Turkish with English summary).

Mohan, B., Kadirvel, R., Natarajan, A. \& Bhaskaran, M., 1996. Effect of probiotic supplementation on growth, nitrogen utilization and serum cholesterol in broilers. Br. Poult. Sci. 37, 395-401.

NRC, 1994. Nutrient requirements of poultry (9th ed.). National Academy Press, Washington D.C., USA.

Öztürk, E. \& Yıldırım, A., 2005. Prebiotics supplementation to the diets broiler on performance and intestinal microbiological characteristics. III. Nat. Anim. Nutr. Congr. 69-75. (Turkish with English summary).

Patterson, J.A. \& Burkholder, K.M., 2003. Application of prebiotics and probiotics in poultry production. Poult. Sci. 82, 627-631.

Pelicia, K., Mendes, A.A., Saldanha, E.S., Piazzolante, C. \& Takahashi, S., 2004. Probiotic and prebiotic utilization in diets for free-range broiler chickens. Br. J. Poult. Sci. 92, 99-104. 
Piray, A.H., Kermanshahi, H., Tahmasbi, A.M. \& Bahrampour, J., 2007. Effects of cecal cultures and aspergillus meal prebiotic (fermacto) on growth performance and organ weights of broiler chickens. Int. J. Poult. Sci. 6, 340-344.

Safalaoh, A.C.L., 2006. Body weight gain, dressing percentage, abdominal fat and serum cholesterol of broilers supplemented with a microbial preparation. African. J. Food. Agric. Nutr. 6, 1-10.

Sahane, M.S., 2001. Mannanoligosaccharides in poultry nutrition: Mechanism and benefits. Proc. Alltech's $17^{\text {th }}$ Annual Symp. Eds. Lyons, T.P. \& Jacques, K.A., Nottingham University Press. 65-77.

Sanchez, R. \& Ayaya, J.A., 1998. Effect of MOS on broiler of performance under field conditions. Alltech's INC. July. 16.

Savage, T.F., Cotter, P.F. \& Zakrzewska, E.I., 1996. The effect of feeding mannanoligosaccharide on immunoglobulins, plasma IgG and bile IgA of Wrolstad MW male turkeys. Poult. Sci. 75, (Suppl. 1), 143.

Sims, M.D. \& Sefton, A.E., 1999. Comparative effects of a manan oligosaccharide and an antibiotic growth promoter on performance of commercial tom turkeys. 48th Western Poultry Disease Conf., Vancouver, Canada. 1999; 78-82.

SPSS Inc., 1999. SPSS for windows (Release 10.0) Standard Version. SPSS Inc. Headquarters, 233 S. Wacker Drive, 11 th floor Chicago, Ilinois 60606, USA.

Waldroup, P.W., Fritts, C.A. \& Fengland, Y., 2003. Utilization of Bio-Mos ${ }^{\circledR}$ mannan oligosaccharide and Bioplex ${ }^{\circledR}$ copper in broiler diets. Int. J. Poult. Sci. 2, 44-52.

Walker, W.A. \& Duffy, L.C., 1998. Diet and bacterial colonization: role of probiotics and prebiotics. J. Nutr. Biochem. 9, 668-675.

Yeo, J. \& Kim, K., 1997. Effect of feeding diets containing an antibiotic, a probiotic, or Yucca extract on growth and intestinal urease activity in broiler chicks. Poult. Sci. 76, 381-385. 